\title{
Problems of Self-Care Activities Encountered in Rheumatoid Arthritis and Their Relationship with Disease Activity and Hand Deformity
}

\author{
Romatoid Artritte Kendine Bakım Aktivitelerinde Karşılaşılan Sorunlar ile \\ Hastalık Aktivitesi ve El Deformitesi Arasındaki İlişki \\ Mine KÖYBAŞI, Figen AYHAN, Pınar BORMAN, Rezan YORGANCIOĞLU \\ $1^{1^{s t}}$ Departments of Physical Medicine and Rehabilitation, Ankara Training and Research Hospital, Ankara, Turkey
}

Objectives: We aimed to investigate the impairments in the following basic self-care domains of the Health Assessment Questionnaire (HAQ): dressing and grooming, eating, and hygiene and to determine the relationships between these impairments and disease activity and deformity in this study.

Patients and methods: A total of 152 patients (113 females, 39 males; mean age $52.3 \pm 14.1$ years; range 24 to 80 years) with rheumatoid arthritis were included in this study. Disease activity was measured by the American College of Rheumotology (ACR) tender and swollen joint counts, the visual analog scalepain (VAS-pain), patient and physician global assessments, the Disease Activity Score of 28 joints (DAS28), the erythrocyte sedimentation rate (ESR), and C-reactive protein (CRP). The functional state was evaluated using $\mathrm{HAQ}$.

Results: The mean score of DAS28 was $4.5 \pm 1.4$. The mean ACR tender and swollen joint counts were $11.1 \pm 1.9$ and $0.7 \pm 0.2$, respectively. The mean patient and physician global assessment scores were $5.2 \pm 2.5$ and $4.7 \pm 2.4$, respectively. There were statistically significant relationships between the functional limitations in all self-care domains of the HAQ and DAS28, ACR tender joint count, VAS-pain, patient and physician global assessment, ESR, and joint deformity $(p<0.01)$. Cutting meat and getting on and off the toilet were the most affected self-care activities.

Conclusion: Many impairments can be detected in self-care activities of patients with rheumatoid arthritis. Rehabilitation strategies should be developed according to the indicated impairment. The self-care domains of HAQ were found to be associated with clinical disease activity in this patient group.

Key words: Hand deformity; Health Assessment Questionnaire; rheumatoid arthritis; self care.
Amaç: Bu çalışmada Sağlık Değerlendirme Anketi'nin (SDA) temel öz bakım alarından olan giyinme ve kendi kendine çeki düzen verme, yemek yeme ve hijyen aktivitelerindeki bozulmalar belirlendi ve bu bozulmalarla hastalık aktivitesi ve deformite arasındaki ilişkiler araştırıldı.

Hastalar ve yöntemler: Çalışmaya romatoid artritli toplam 152 hasta (113 kadın, 39 erkek; ort. yaş $52.3 \pm 14.1$ yıl; dağılım 24-80 yıl) alındı. Hastalık aktivitesi; American College of Rheumatology (ACR) hassas ve şiş eklem sayısı, görsel analog ölçeği-ağrı (GAÖ-ağrı), hasta ve hekimin global değerlendirmesi, 28 eklemin Hastalık Aktivite Skoru (DAS28), eritrosit sedimantasyon hızı (ESH) ve C-reaktif protein (CRP) ile ölçüldü. Fonksiyonel durum SDA ile değerlendirildi.

Bulgular: Ortalama DAS28 skoru 4.5 \pm 1.4 idi. Ortalama ACR hassas ve şiş eklem sayısı sırasıyla $11.1 \pm 1.9$ ve $0.7 \pm 0.2$ idi. Hasta ve hekimin global değerlendirme skorları sırasıyla $5.2 \pm 2.5$ ve $4.7 \pm 2.4$ idi. Tüm SDA özbakım alanlarındaki fonksiyonel kısıtlamalarla DAS28 skoru, ACR hassas eklem sayısı, GAÖ-ağrı, hasta ve hekim global değerlendirmesi, ESH ve eklem deformitesi arasında anlamlı pozitif ilişkiler saptandı $(p<0.01)$. Et kesme ve tuvalete oturma ve kalkma en çok etkilenen özbakım aktiviteleri idi.

Sonuç: Romatoid artritli hastalarda özbakım aktivitelerinde birçok bozukluk saptanabilir. Saptanan bozukluğa göre rehabilitasyon stratejileri geliştirilmelidir. Sağlık değerlendirme anketi özbakım alanları bu hasta grubunda, klinik hastalık aktivitesiyle ilişkili bulundu.

Anahtar sözcükler: El deformitesi; Sağlık Değerlendirme Anketi; romatoid artrit; kendine bakım. 
Rheumatoid arthritis (RA) is a systemic, inflammatory and destructive disease that primarily targets synovial joints. Acute exacerbations can be observed in the course of RA and these exacerbations result in pain, stiffness and immobilization due to inflammation and synovitis. As the disease progresses, decreased joint movements, subluxation, tendon instabilities and joint damage occurs in the chronic course of the disease. Volar subluxation and ulnar deviation in metacarpophalangeal joints, Boutonnière and swan-neck deformities in interphalangeal joints, or Z deformity in the thumb may be seen in this period of disease. $^{[1]}$

Since the disease itself or its complications inevitably affect RA patients' functional status and life quality, assessment of functional limitations must be performed. The Health Assessment Questionnaire (HAQ) commonly used in clinical practice for RA is an index that evaluates physical functions and is quite sensitive to clinical changes. It can also be performed by the patients themselves. ${ }^{[2]}$

Bruce and Fries ${ }^{[3]}$ of Stanford University developed the HAQ in 1978 and Küçükdeveci et al. ${ }^{[4]}$ evaluated the validity and reliability of its Turkish version. The HAQ assesses upper and lower extremity functions in daily life activities, and it is a strong indicator of future possible disabilities and early death. The HAQ also evaluates early response to the treatment. ${ }^{[5]}$

The goal of this cross-sectional study is to specifically define the type and degree of self-care difficulties by using the relevant questions in the HAQ and to determine the relation between disease activity and deformity.

\section{PATIENTS AND METHODS}

A total of 152 participants (113 females, 39 males; mean age $52.3 \pm 14$.1 years; range 24 to 80 years) followed up by the rheumatology unit of our clinic between November 2005 and December 2006 were included in this study. All patients were diagnosed with RA according to the 1987 American College of Rheumatology (ACR) classification criteria ${ }^{[6]}$ Patients' demographic features and duration of disease were noted. Rheumatologic examinations were performed on all patients and upper extremity deformities were determined.

A seven-item core data set of the ACR was used to evaluate disease activity. Sixty-eight joints were assessed for tenderness (all 68) and swelling (only 66) by the core data set. In addition, visual analog scale-pain (VAS-pain), patient and physician global assessment, acute phase reactants (sedimentation and C-reactive protein) in blood samples were recorded. Physical function was evaluated to assess functional status in the daily living activities of the patients. ${ }^{[7-9]}$

Disease activity score 28 (DAS28) is a validated instrument that measures disease activity in patients with RA. DAS28 was calculated by 28 tender joints, 28 swollen joints, the erythrocyte sedimentation rate (ESR) as an acute phase reactant, and the global assessment of the patient. ${ }^{[10,11]}$ Pain scores are measured by using horizontal VAS ranging from 0 to $10 \mathrm{~cm}$.

The Turkish version of HAQ was used to evaluate functional limitations and disability. ${ }^{[4]}$ The HAQ is composed of eight categories (dressing \& grooming, arising, eating, walking, hygiene, reach, grip and common daily activities), and each category has two to three subcategories resulting in a total of 20 questions. Scoring conventions range from 0 to 3 (0: without any difficulty, 1: with some difficulty, 2 : with much difficulty, 3: unable to do), and the highest score reported by the patient for any component question of the eight categories determines the score for that category. Higher HAQ scores indicate poor results while lower HAQ scores indicate better results. The reference time frame for these questions was the previous week.

In the present study to assess basic self-care domains of the HAQ, questions and answers were evaluated regarding the following: dressing and grooming (dressing oneself, shampooing hair), eating (cutting meat, lifting a full cup or glass to the mouth) and hygiene (washing and drying the body, getting on and off the toilet).

Rheumatoid hand deformities were categorized as present or absent of volar subluxation and ulnar deviation in metacarpophalangeal joints, Boutonnière and swan-neck deformities in interphalangeal joints, or $\mathrm{Z}$ deformity in the thumb.

SPSS 15.0 version software (SPSS Inc., Chicago, Illinois, USA) descriptive statistics and Spearman correlation analysis were used in statistical analysis. $P<0.05$ was accepted as statistically significant.

\section{RESULTS}

The average disease duration was $16.7 \pm 16.5$ years. The average DAS28 score was calculated as $4.5 \pm 1.4$. The mean age, disease duration, erythrocyte sedimentation rate and CRP values of the patients and DAS28 scores are shown in Table 1. 
Table 1. Demographic features and disease activity parameters of the patients

\begin{tabular}{lccc}
\hline & Mean \pm SD & Median & (min-max) \\
\hline Mean age (years) & $52.3 \pm 14.1$ & 53 & $(24.0-80.0)$ \\
Average disease duration (years) & $16.5 \pm 16.1$ & 10 & $(1-68)$ \\
Erythrocyte sedimentation rate (mm/hour) & $37.9 \pm 26.1$ & 33.5 & $(2-120)$ \\
ACR-tender joint count & $11.1 \pm 10.0$ & 10 & $(0-59)$ \\
ACR-swollen joint count & $0.6 \pm 0.2$ & 0 & $(0-17)$ \\
Visual analog scale-pain & $5.7 \pm 2.7$ & 6 & $(0-10)$ \\
Patient global assessment & $5.2 \pm 2.5$ & 5 & $(0-10)$ \\
Physician global assessment & $4.6 \pm 2.3$ & 5 & $(0-10)$ \\
Score of Disease Activity Score 28 & $4.5 \pm 1.4$ & 4.61 & $(1.13-7.55)$ \\
C-reactive protein (mg/lt) & $5.4 \pm 2.5$ & 0.97 & $(0.10-46.30)$ \\
\hline SD: Standard deviation; ACR: American College of Rheumatology. & & \\
\hline
\end{tabular}

The frequencies and percentages of the HAQ domain scores for dressing and grooming, eating, and hygiene are demonstrated in Table 2. Rheumatoid hand deformities were detected in $57.8 \%$ of the patients.

A strong correlation $(\mathrm{p}<0.01)$ was observed between all the HAQ subcategories and DAS28, the ACR tender joint number, patient and physician global assessment and sedimentation, but no correlation was found with CRP. The ACR swollen joint number was only correlated with the lifting of a full cup or glass to the mouth $(\mathrm{r}=0.02, \mathrm{p}=0.008)$. Hand deformities were strongly correlated with dressing oneself, shampooing hair, washing and drying the body and getting on and off the toilet while there was a weak correlation between hand deformities and lifting a full cup or glass to the mouth. The results of a Spearman correlation analysis are shown in Table 3.

\section{DISCUSSION}

According to the results of the present study completed in our clinic's Rheumatology Unit, a relation between the HAQ self-grooming subcategory scores and disease activity and hand deformities was noted. Functional limitations in all these subcategory activities were found

Table 2. Frequency analysis of Health Assessment Questionnaire self care subgroup

\begin{tabular}{|c|c|c|c|c|c|c|c|c|}
\hline \multirow[t]{2}{*}{ HAQ-Subgroup } & \multicolumn{2}{|c|}{$\begin{array}{c}\text { Without any } \\
\text { difficulty }\end{array}$} & \multicolumn{2}{|c|}{$\begin{array}{l}\text { With some } \\
\text { difficulty }\end{array}$} & \multicolumn{2}{|c|}{$\begin{array}{c}\text { With much } \\
\text { difficulty }\end{array}$} & \multicolumn{2}{|c|}{ Unable to do } \\
\hline & $\mathrm{n}$ & $\%$ & $\mathrm{n}$ & $\%$ & $\mathrm{n}$ & $\%$ & $\mathrm{n}$ & $\%$ \\
\hline Dressing & 38.8 & 59 & 28.3 & 43 & 26.3 & 40 & 6.6 & 10 \\
\hline Grooming & 38.7 & 59 & 27.0 & 41 & 25.7 & 39 & 8.6 & 13 \\
\hline Cutting meat & 30.4 & 46 & 23.2 & 35 & 25.2 & 38 & 21.2 & 32 \\
\hline Lifting glass to mouth & 42.7 & 65 & 29.6 & 45 & 22.4 & 34 & 5.3 & 8 \\
\hline Taking a bath & 41.4 & 63 & 25.1 & 38 & 21.7 & 33 & 11.8 & 18 \\
\hline Getting on and off the toilet & 33.1 & 50 & 15.9 & 24 & 39.1 & 59 & 11.9 & 18 \\
\hline
\end{tabular}

Table 3. Spearman correlation analyses between domains of Health Assessment Questionnaire self care subgroup and disease activity

\begin{tabular}{|c|c|c|c|c|c|c|}
\hline HAQ self-care & $\mathrm{D}(\mathrm{r})$ & $\mathrm{G}(\mathrm{r})$ & $\mathrm{CM}(\mathrm{r})$ & LG (r) & $\mathrm{TB}(\mathrm{r})$ & GT (r) \\
\hline Disease Activity Score 28 & $0.497^{\star *}$ & $0.488^{\star *}$ & $0.475^{\star *}$ & $0.368^{* *}$ & $0.443^{\star *}$ & $0.476^{\star *}$ \\
\hline ACR tender joint count & $0.523^{\star *}$ & $0.511^{\star *}$ & $0.582^{\star *}$ & $0.424^{\star *}$ & $0.417^{* *}$ & $0.448^{\star *}$ \\
\hline Visual analog scale-pain & $0.311^{\star *}$ & $0.272^{\star *}$ & $0.329^{\star *}$ & $0.299^{\star *}$ & $0.326^{* *}$ & $0.312^{\star *}$ \\
\hline Patient global assessment & $0.332^{\star \star}$ & $0.252^{* *}$ & $0.225^{\star}$ & $0.257^{\star *}$ & $0.309^{\star *}$ & $0.295^{\star *}$ \\
\hline Physician global assessment & $0.372^{\star *}$ & $0.301^{\star *}$ & $0.264^{\star *}$ & $0.272^{\star *}$ & $0.297^{\star *}$ & $0.300^{\star *}$ \\
\hline Hand deformity & $0.218^{\star \star}$ & $0.187^{\star}$ & 0.109 & $0.194^{\star}$ & $0.245^{\star *}$ & $0.254^{\star \star}$ \\
\hline Erythrocyte sedimentation rate $(\mathrm{mm} / \mathrm{hr})$ & $0.307^{\star *}$ & $0.335^{\star *}$ & $0.261^{\star \star}$ & $0.173^{*}$ & $0.390^{\star *}$ & $0.412^{* *}$ \\
\hline
\end{tabular}


to be related to some basic parameters (DAS28 score, ACR tender joint number, VAS-pain score, patient and physician global assessment scores, and sedimentation rate) indicating disease activity. Additionally, there was a relationship between hand deformities and difficulties faced during dressing and hygiene activities. In any of the currently available studies, the HAQ subcategories were not evaluated separately. Our study is the first that assesses basic self-grooming activities. We planned to establish individual rehabilitation goals by specifying the most affected activity in those subcategories.

Our study results were found to be similar to the study that was done by Pincus et al..$^{[12]}$ and Borman et al. ${ }^{[13]}$ suggesting a correlation between the HAQ scores and pain scores, affected joint number, sedimentation rate, and physician assessment and patient selfassessment scores. Another study reported that there was a strong relation between disability and pain in 186 RA patients in remission. ${ }^{[14]}$ However, the same study showed a weaker association between joint damage, disease duration and disease activity. It was found that tender joint number was an indicator of the HAQ scores in the three-year follow-up of 149 early RA patients. ${ }^{[15]}$

In other studies, disease activity was not only associated with joint destruction, but also age, gender, psychological status, education level, muscle strength and comorbidity ${ }^{[16,17]}$ For instance, Wolfe ${ }^{[2]}$ showed that disability assessed by the HAQ in RA was associated with disease activity, pain, and psychosocial factors and suggested that the HAQ was a good long-term indicator of disability in RA. They also reported that functional limitation defined by the HAQ was mostly related to pain.

Welsing et al. ${ }^{[18]}$ followed $321 \mathrm{RA}$ patients for nine years and found that gradually decreasing functional capacity was more affected by disease activity in early RA and by joint destruction in late RA. Functional impairments occur due to the inflammatory process assessed by disease activity in the early period ( $<5$ years) of RA and joint destruction in the late phase ( $>5$ years) of RA. ${ }^{[19]}$ Another study that was done with 138 female RA patients followed up for 12 years suggested that functional capacity assessed by the HAQ was strongly associated with disease activity and joint destruction. It also found that disease activity was a stronger indicator of functional capacity. ${ }^{[20]}$ In corresponding with those results, we showed that disease activity (DAS28, ESR, ACR tender joint number) were related to the HAQ subcategories in our patients with a mean disease duration of 16 years.
Although there is no sufficient evidence supporting the fact that comprehensive occupational therapy improves functional abilities, devices helping with the daily life activities for patients with hand deformities are often recommended. ${ }^{[21]}$ In our patient population, RA patients experienced the most difficulties in cutting meat and getting on and off the toilet. These functional limitations may occur due to the disease activity as well as the presence of hand deformities and the arthritic process seen in the lower extremities. Patients may benefit from recommendations to cut their meat in small chunks and to use sharp knives, broad-handled utensils along with deep bowls in the kitchen. Also, they may prefer Western toilets in their bathroom.

The goal of RA treatment must be to prevent disease activity and joint destruction in the early stages by using disease-modifying, anti-rheumatic drug treatments and by the early detection of impairments in self-care activities to establish rehabilitation strategies. It is known that early treatment with disease-modifying, anti-rheumatic drugs results in a decreased rate of the HAQ score increments. Treatment can control disease activity, decrease joint damage and improve functional results. ${ }^{[5]}$ Rehabilitation strategies should be developed according to detected impairments. Since our study results showed that the HAQ self-care subcategory is associated with clinical disease activity and hand deformities, we suggest that early intervention and disease control in conjunction with the recommended use of suitable utensils are clinically important in the management of patients suffering from RA.

\section{Declaration of conflicting interests}

The authors declared no conflicts of interest with respect to the authorship and/or publication of this article.

\section{Funding}

The authors received no financial support for the research and/or authorship of this article.

\section{REFERENCES}

1. Gordon DA, Hastings DE. Clinical features of rheumatoid arthritis. In: Hochberg MC, Silman AJ, Smolen JS, Wenblatt ME, Weisman MH, editors. Rheumatology. 3rd ed. London: Mosby; 2003. p. 765-78.

2. Wolfe F. A reappraisal of HAQ disability in rheumatoid arthritis. Arthritis Rheum 2000;43:2751-61.

3. Bruce B, Fries JF. The Stanford Health Assessment Questionnaire: a review of its history, issues, progress, and documentation. J Rheumatol 2003;30:167-78. 
4. Küçükdeveci AA, Sahin H, Ataman S, Griffiths B, Tennant A. Issues in cross-cultural validity: example from the adaptation, reliability, and validity testing of a Turkish version of the Stanford Health Assessment Questionnaire. Arthritis Rheum 2004;51:14-9.

5. Scott DL, Garrood T. Quality of life measures: use and abuse. Baillieres Best Pract Res Clin Rheumatol 2000;14:663-87.

6. Arnett FC, Edworthy SM, Bloch DA, McShane DJ, Fries JF, Cooper NS, et al. The American Rheumatism Association 1987 revised criteria for the classification of rheumatoid arthritis. Arthritis Rheum 1988;31:315-24.

7. Tugwell P, Boers M. Developing consensus on preliminary core efficacy endpoints for rheumatoid arthritis clinical trials. OMERACT Committee. J Rheumatol 1993;20:555-6.

8. van Riel PL. Provisional guidelines for measuring disease activity in clinical trials on rheumatoid arthritis. Br J Rheumatol 1992;31:793-4.

9. Felson DT, Anderson JJ, Boers M, Bombardier C, Chernoff M, Fried B, et al. The American College of Rheumatology preliminary core set of disease activity measures for rheumatoid arthritis clinical trials. The Committee on Outcome Measures in Rheumatoid Arthritis Clinical Trials. Arthritis Rheum 1993;36:729-40.

10. van der Heijde DM, van 't Hof MA, van Riel PL, Theunisse LA, Lubberts EW, van Leeuwen MA, et al. Judging disease activity in clinical practice in rheumatoid arthritis: first step in the development of a disease activity score. Ann Rheum Dis 1990;49:916-20.

11. van der Heijde DM, van 't Hof $M$, van Riel PL, van de Putte LB. Development of a disease activity score based on judgment in clinical practice by rheumatologists. J Rheumatol 1993;20:579-81.

12. Pincus T, Callahan LF, Brooks RH, Fuchs HA, Olsen NJ, Kaye JJ. Self-report questionnaire scores in rheumatoid arthritis compared with traditional physical, radiographic, and laboratory measures. Ann Intern Med 1989;110:259-66.
13. Borman P, Yılmaz L, Gündüz H, Barça N, Duruğ MT. Comparison of functional disability measures and clinical variables in rheumatoid arthritis. Romatoloji ve Tibbi Rehabilitasyon Dergisi 2003;14:150-8.

14. Molenaar ET, Voskuyl AE, Dijkmans BA. Functional disability in relation to radiological damage and disease activity in patients with rheumatoid arthritis in remission. J Rheumatol 2002;29:267-70.

15. van Leeuwen MA, van der Heijde DM, van Rijswijk $\mathrm{MH}$, Houtman PM, van Riel PL, van de Putte LB, et al. Interrelationship of outcome measures and process variables in early rheumatoid arthritis. A comparison of radiologic damage, physical disability, joint counts, and acute phase reactants. J Rheumatol 1994;21:425-9.

16. Escalante A, del Rincón I. How much disability in rheumatoid arthritis is explained by rheumatoid arthritis? Arthritis Rheum 1999;42:1712-21.

17. Spiegel JS, Leake B, Spiegel TM, Paulus HE, Kane RL, Ward NB, et al. What are we measuring? An examination of self-reported functional status measures. Arthritis Rheum 1988;31:721-8.

18. Welsing PM, van Gestel AM, Swinkels HL, Kiemeney LA, van Riel PL. The relationship between disease activity, joint destruction, and functional capacity over the course of rheumatoid arthritis. Arthritis Rheum 2001;44:2009-17.

19. Guillemin F, Briançon S, Pourel J. Functional disability in rheumatoid arthritis: two different models in early and established disease. J Rheumatol 1992;19:366-9.

20. Drossaers-Bakker KW, de Buck M, van Zeben D, Zwinderman AH, Breedveld FC, Hazes JM. Long-term course and outcome of functional capacity in rheumatoid arthritis: the effect of disease activity and radiologic damage over time. Arthritis Rheum 1999; 42:1854-60.

21. Patel AT, Coarbar LM. Upper limb orthotic devices. In: Braddom RL, editor. Physical medicine and rehabilitation. 2nd ed. Philadelphia:W.B. Saunders; 2007. p. 325-43. 